\title{
Phytotherapeutic agents on anxiety control in dentistry: a literature review
}

\author{
Agentes fitoterápicos no controle da ansiedade em odontologia: uma revisão de literatura \\ Agentes fitoterapéuticos sobre el control de la ansiedad en odontología: revisión de la literatura
}

Received: 11/18/2021 | Reviewed: 11/28/2021 | Accept: 11/29/2021| Published: 12/11/2021

\author{
Camila Soares Lopes \\ ORCID: https://orcid.org/0000-0002-7746-1580 \\ Paulista State University “Júlio de Mesquita Filho", Brazil \\ E-mail: milasoares.odonto@gmail.com \\ Suellen de Azevedo Moreira \\ ORCID: https://orcid.org/0000-0001-8640-5401 \\ Federal University of Alfenas, Brazil \\ E-mail: suellenmoreira15@gmail.com \\ Marcela de Come Ramos \\ ORCID: https://orcid.org/0000-0002-6041-6329 \\ Federal University of Alfenas, Brazil \\ E-mail: marcela.ramos@sou.unifal-mg.edu.br \\ Naiana Viana Viola \\ ORCID: https://orcid.org/0000-0001-8097-892X \\ Federal University of Alfenas, Brazil \\ E-mail: naviolinha@yahoo.com.br
}

\begin{abstract}
The aim of this work is to review the literature on the use of herbal medicines to control dental anxiety. For this purpose, articles were searched in the databases ScienceDirect, Pubmed and The Cochrane Library. 57 articles were included in this study. The research evidence points to Valeriana officinalis and Passiflora incarnata as the most studied herbal medicines for the control of anxiety, and their adverse effects are also investigated. Studies prove the relative safety of these medications, as well as their effectiveness, low cost, lower concentration of active ingredients with better effects and fewer side effects when compared to benzodiazepines. The use of these medicinal plants requires further clarification as to their real effectiveness, correct dosage and side effects in conscious sedation in Dentistry.
\end{abstract}

Keywords: Dental anxiety; Dentistry; Phytotherapy.

\section{Resumo}

O objetivo deste trabalho é revisar a literatura acerca do uso de fitoterápicos no controle da ansiedade odontológica. Para tanto, foram pesquisados artigos nas bases de dados ScienceDirect, Pubmed and The Cochrane Library. 57 artigos foram incluídos neste estudo. As evidências da pesquisa apontam a Valeriana officinalis e Passiflora incarnata como os fitoterápicos mais estudados para o controle da ansiedade, inclusive são investigados seus efeitos adversos. Estudos comprovam a relativa segurança no uso desses medicamentos, bem como sua eficácia, baixo custo, menor concentração de princípios ativos com melhores efeitos e menores efeitos colaterais quando comparados aos benzodiazepínicos. O uso dessas plantas medicinais requerem maiores esclarecimentos quanto à sua real eficácia, dosagem correta e efeitos colaterais na sedação consciente em Odontologia.

Palavras-chave: Ansiedade ao tratamento Odontológico; Fitoterapia; Odontologia.

\section{Resumen}

El objetivo de este trabajo es revisar la literatura sobre el uso de medicamentos a base de hierbas para controlar la ansiedad dental. Para ello, se realizaron búsquedas de artículos en las bases de datos ScienceDirect, Pubmed and The Cochrane Library. En este estudio se incluyeron 57 artículos. La evidencia de la investigación apunta a Valeriana officinalis y Passiflora incarnata como las hierbas medicinales más estudiadas para el control de la ansiedad, y también se investigan sus efectos adversos. Los estudios demuestran la seguridad relativa de estos medicamentos, así como su efectividad, bajo costo, menor concentración de ingredientes activos con mejores efectos y menos efectos secundarios en comparación con las benzodiazepinas. El uso de estas plantas medicinales requiere una mayor aclaración en cuanto a su efectividad real, correcta dosificación y efectos secundarios en la sedación consciente en Odontología.

Palabras clave: Ansiedad al tratamiento odontológico; Fitoterapia; Odontología. 


\section{Introduction}

Anxiety is an important component of patients' stress in the dental office, which affects 10 to $60 \%$ of the population (Deogade \& Suresan, 2016). Despite technological and scientific advances and the improvement of techniques, mainly for pain control, dental treatment can still awaken the feeling of fear, the intensity of which fluctuates between one patient and another (Dantas et al., 2016; Facco \& Zanette, 2017; da Cunha et al., 2021;). Invasive dental procedures, such as anesthesia, are related to fear and anxiety. In addition, these feelings may be related to culture, previous experience and gender (Vanhee et al., 2020). All this uncomfortable situation can cause even the calmest patients to have anxiety peaks before the treatment sessions (Araújo et al., 2018; Farah et al., 2019; da Cunha et al., 2021).

Anxiety may have a negative impact on dental treatment which can culminate in damage to oral health (Pinheiro et al., 2014; da Cunha et al., 2021). Anxious, fearful, or phobic patients delay or avoid seeking oral health care, despite needing treatment (Deogade \& Suresan, 2016; Araújo et al., 2018). In addition, the symptoms of anxiety may disturb the performed dental procedure, thus compromising patient safety and quality of treatment (Facco \& Zanette, 2017) and even leading to damage to their quality of life (da Cunha et al., 2021).

To circumvent this situation and control patients' anxiety, several pharmacological and non-pharmacological interventions can be used. When only non-pharmacological approaches are insufficient, sedation techniques can be used to control this sensation (Gordon et al., 2013; da Cunha et al., 2021). This technique is called minimal sedation and is defined by the American Dental Association as the "minimally depressed level of consciousness that allows the patient to keep their airways functioning independently and respond to physical stimuli and verbal commands" (Mancuso et al., 2004; da Cunha et al., 2021).

The administration of oral tranquilizing drugs is an alternative for conscious sedation. Premedication controls stress triggered by the performed procedure, making the patient calm and cooperative (Loeffler, 1992). The drugs that are commonly used in dentistry are the oral benzodiazepines which provide reduction of basal metabolism, salivary flow and vomit reflex, and relaxation of skeletal muscles (Pinheiro et al., 2014).

However, despite its low toxicity, benzodiazepines may present adverse reactions such as exanthema, nausea, and headache. They can also potentiate the effect of ethyl alcohol and promote the paradoxical effect (Pinheiro et al., 2014). In addition, they may trigger adverse effects such as sleepiness, mental confusion, anterograde amnesia, decreased motor coordination, and psychomotor effect (Fajemiroye et al., 2016; Farah et al., 2019; da Cunha et al., 2021). These unwanted effects cause new alternatives for minimal sedation in dental offices to be researched (Araújo et al., 2018; Farah et al., 2019; da Cunha et al., 2021).

Phytoterapy has been widely used and generally accepted as established treatment of depressive disorders, leading to the investigation of its potential as a treatment form of various anxiety disorders (Kinrys et al., 2009; Liu et al., 2015; Fajemiroye et al., 2016). Phytotherapy is defined as the treatment of ailments using fresh vegetables, plant drugs, or vegetable extracts prepared with these type of raw material (Fajemiroye et al., 2016).

The objective of this study is to review the literature and arouse the interest of health professionals, especially dental surgeons, to develop controlled trials testing the efficacy of phytotherapeutic medication, which can be a viable and safe alternative to control anxiety in Dentistry, without the occurrence of unpleasant sensations to the patients. Use the paragraph as a template.

\section{Methodology}

This is a narrative review whose guiding question was: "Can herbal medicines be used to control dental anxiety?". To 
answer this question, the following databases were consulted: ScienceDirect, Scielo, Pubmed and The Cochrane Library, using the following keywords: "Dental Anxiety" and "Dentistry" or "Odontology" and "Phitotherapy".

The inclusion criteria consisted of articles published between 2001 and 2021, regardless of the language of publication. Articles that did not address the use of herbal medicines to control dental anxiety and those that could not be accessed in full were excluded.

The free-web tool for review management (Rayyan QCRI®) (Ouzzani et al., 2016) was used to collect references and remove duplicate articles. The same search strategies will be run on every update.

\section{Results and Discussion}

The literature search resulted in 235 hits. After the removal of the duplicates, broad screening by title and abstract, retrieval of those selected for appraisal and critical evaluation by eligibility criteria in full-text version, and assessment in full length of them, 57 papers composed the sample of this review. The flow diagram detailing the steps of identification, screening, and inclusion is available in Figure 1.

Figure 1. illustrates the flowchart that details the entire sequence of location, identification and final inclusion of the 57 articles.

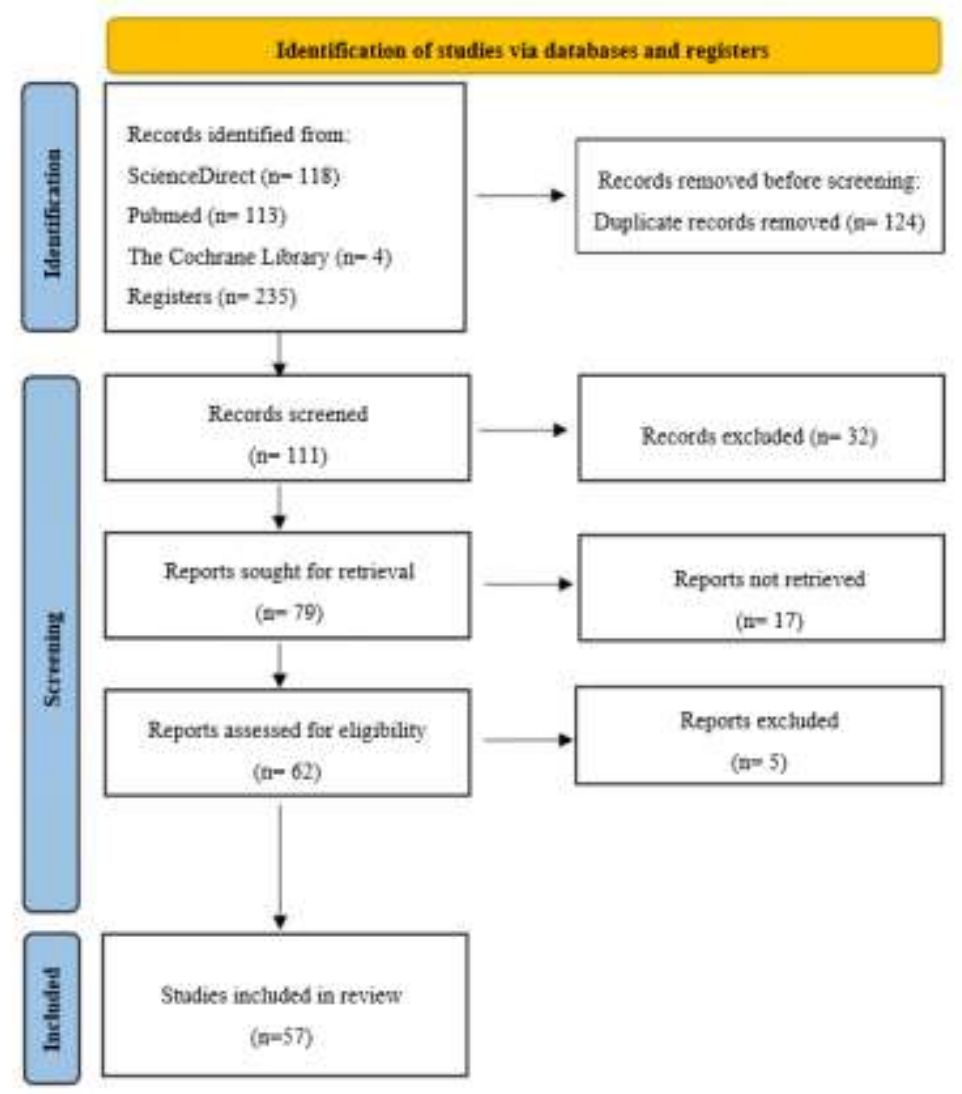

Source: Authors.

\subsection{Phytotherapy}

Herbal medicines with anxiolytic and hypnotic properties have aroused growing interest in different areas of medicine due to the low incidence of side effects (Farah et al., 2019). Research in the area of plant-based 
psychopharmacology has revealed a variety of promising drugs that may provide benefits in the treatment of general anxiety and specific anxiety disorders (Sarris et al., 2013; Liu et al., 2015).

Recently, the area of plant-based psychopharmacology has received much attention from researchers. There is a variety of described mechanisms of action of medicinal plants used to treat depression, anxiety and insomnia, involving the reuptake of monoamines, which affects the activity of the neuroreceptor and the transporter channel, modulating neuronal communication or the hypothalamic-pituitary-adrenal axis (Liu et al., 2015).

The mechanism of action of medicinal plants that have anxiolytic properties usually exert effects on GABA (gammaaminobutyric acid), the main inhibitory neurotransmitter of the central nervous system (CNS). In addition, these effects may be on the connection with its receptor, through direct action on ion channels, on cell membrane modulation, on the inhibition of GABA transaminase, or on the inhibition of glutamic acid decarboxylase. The subsequent increase in GABA neurotransmission has a hindering effect on stimulatory pathways, which ultimately has a calming effect (Baldwin \& Polkinghorn, 2005; Manayi et al., 2016; Sarris et al., 2018; Farah et al., 2019).

Currently, there is a growing interest in phytotherapy among professionals and patients. The plants are rich sources of biomolecules with therapeutic values for the treatment of anxiety (Liu et al., 2015; Fajemiroye et al., 2016). However, healthcare professionals lack information about the correct use of phytoterapy, which makes them question its effectiveness. Such information needs to be available to these professionals through scientific dissemination, so that the use of phytotherapy is encouraged, safeguarding the patient's health and consolidating such an important therapeutic aspect (Sarris et al., 2013).

In dentistry, phytomedicine has been used to increase pain threshold and as a sedative. It is important that the use of herbal medicines and other natural products have a correct application involving their therapy, side effects, and possible drug interactions (Groppo et al., 2008).

However, the use of phytotherapeutic agents in dental practice is still very recent (Groppo et al., 2008; Pinheiro et al., 2014). Which makes it difficult to search for texts or research related to the subject.

Current pharmacological approaches to anxiety management are pursuing desirable outcomes in clinical practice. Medicinal plants provide opportunities for the development of anti-anxiety and antidepressant drugs (Fajemiroye et al., 2016; Facco \& Zanette, 2017).

\subsection{Valeriana (Valeriana officinalis)}

Valeriana officinalis is an herbaceous plant belonging to the family Valerianaceae (Houghton, 1999). It is included in many phytoterapeutic products with anxiolytic and hypnotic properties (Murphy et al., 2010; Becker et al., 2014; Farah et al., 2019). Its properties include promoting central nervous system relaxation, decreasing stress and anxiety, and improving sleep with few or practically no side effects (Behboodi et al., 2016; Farah et al., 2019).

The chemical composition of valerian includes volatile oil sesquiterpenes (including valeric acid), iridoids (valepotriates), alkaloids, furanofuran, lignans, and free amino acids such as tyrosine, arginine, and glutamine. Although it is believed that the sesquiterpene components of volatile oil are responsible for most of the biological effects of valerian, it is likely that all of the active constituents of valerian act synergistically to produce a clinical response (Houghton, 1999).

The mixture of the three active principles valepotriates, sesquiterpenes, and lignans promote actions analogous to those of tranquilizers, hypnotics, and sedatives (Hadley \& Petry, 2003).

The medicinal properties of Valeriana officinalis are attributed to its volatile oils, valepotriates, and their precursors (Houghton, 1999; Ricigliano et al., 2016). Valerenic acid and valerenol improved the response of various types of recombinant GABA receptors (Becker et al., 2014). These oils inhibit the enzyme responsible for the metabolism of GABA in the brain, 
consequently increasing GABA levels, which is associated with sedation and decreased CNS activity, confirming its central and non-peripheral action (Thomas et al., 2016).

The effects of the valerian extract on diazepam withdrawal syndrome in rats showed reversion of the anxiogenic effects in the abstinent animals treated with valerian $12 \mathrm{mg} / \mathrm{Kg}$ of body weight (Andreatini \& Leite, 1994).

Because valerenic acid is capable of interacting with the GABA system, a mechanism of action similar to benzodiazepine drugs, a study in rats compared the effects of this herb with diazepam and analyzed its chemical composition. The results showed a significant reduction in the anxiety behavior of the animals that received the valerian extract and valerenic acid, therefore confirming the evidence that Valeriana officinalis is a viable alternative to traditional anxiolytics (Murphy et al., 2010). Recently, in another study with rats submitted to physical or psychological stress, the administration of $0.5 \mathrm{mg} / \mathrm{Kg}$ of valerenic acid once daily for 3 weeks decreased the response to physical and psychological stress (Jung et al., 2015).

In clinical trials they demonstrated the sedative and hypnotic effect of valerian at a dosage of 400 to $900 \mathrm{mg}$ administered 30 to 60 minutes before bed. Furthermore, unlike benzodiazepines, valerian extracts did not interfere with voluntary movement and speech coordination and did not lead to physical and / or psychological dependence (Pakseresht et al., 2011).

A double-blind clinical trial assessed the level of anxiety of women undergoing hysterosalpingography, a stressful and painful procedure, after using the herb in capsules. In this study, three valeric capsules containing 500 $\mathrm{mg}$ were given in a single dose (1,500 $\mathrm{mg}$ total), along with prophylaxis, 30 minutes before the procedure. They found that the valeric drug was effective in reducing anxiety in women undergoing this test (Gharib et al., 2015).

Another study evaluated the effectiveness of Valerian in the control of anxiety in patients submitted to bilateral extraction of impacted third molars. Valerian $100 \mathrm{mg}$ or placebo was administered orally in a single dose an hour prior to the initiation of surgical procedures. They concluded that Valerian has an anxiolytic effect and can be used for conscious sedation of adult patients submitted to the extraction of impacted mandibular third molars. It was also observed that this phytotherapeutic agent does not induce anterograde amnesia, since the patients reported remembering all the events related to the surgical procedure (Pinheiro et al., 2014).

In the study conducted by Farah et al (2019), 20 anxious patients with indication for bilateral extraction of lower third molars were selected to perform the surgery and to conduct the research, and on the day of the procedure, patients received capsules containing $100 \mathrm{mg}$ of valerian or $15 \mathrm{mg}$ of midazolam orally 60 minutes before procedures in a randomized crossover, split mouth. As a result, it was not possible to identify changes in physiological parameters that were assessed at specific times during surgery. In addition, in the postoperative period, patients completed a questionnaire self-assessing their level of anxiety. This questionnaire pointed out that when Valerian was used, no patient reported anterograde amnesia while the use of midazolam caused this effect in $40 \%$ of respondents, which may have a direct effect in the fact that $55 \%$ of patients prefer the surgery in which valerian was administered. in direct comparison to midazolam. These results demonstrated that valerian appears to have the potential to provide patients with the necessary comfort and relaxation without sedation and less drowsiness than midazolam.

The literature shows studies of the effect of the Valerian Officinalis extract on the treatment of generalized anxiety disorder (GAD) (Andreatini \& Leite, 1994; Pakseresht et al., 2011) and insomnia (Fernández-San-Martín et al., 2011). It also show that $\mathrm{V}$. officinalis is capable of reducing emotional, physical, and behavioral symptoms of premenstrual syndrome (Behboodi et al., 2016). It prevents neuropsychiatric adverse effects, such as sleepiness and anxiety, in HIV positive patients (Ahmadi et al., 2017). In addition, the ability of V. officinalis to exert 
neuroprotective effects on several neurodegenerative diseases, such as Parkinson's disease and Alzheimer's disease, was reported (Pereira et al., 2011).

Other studies reported that V. officinalis showed low toxicity (Bos et al., 1998; Yao et al., 2007). A review of the literature has shown that Valerian is considered a safe herb in most studies, and the only reported adverse effect was diurnal sleepiness, but only at higher doses. In addition, no harmful side effects have been reported (Kinrys et al., 2009; Baek et al., 2014). This fact was also observed in the study by Pinheiro et al. (2014), in which adverse effects such as dizziness, gastrointestinal problems, signs of allergy or the paradoxical effect were not reported.

Studies have also shown that the use of Valeriana officinalis extracts does not produce side effects, such as dizziness, gastrointestinal problems, allergy, or the paradoxical effect (Pinheiro et al., 2014). Additionally, Yao et al. (2007) verified that the ethanolic extract of V. officinallis did not have adverse effects on embryonic development and fertility of rodents.

Currently, one study assessed the effects of a single dose of Valerian $(1600 \mathrm{mg})$ on sedation through the standardized field sobriety test and performance parameters of a driving simulator. The authors verified that the acute intake of the phytotherapeutic agents did not affect performance of the participants in the driving simulator (Thomas et al., 2016).

Furthermore, valerian does not potentiate the effects of alcohol or CNS depressants, does not interfere with the ability to drive vehicles or operate machines, and does not cause physical and/or psychological dependence (Ugalde et al., 2005). However, Hendriks et al. (1985) and Leuschner; Müller; Rudmann (1993) stated that Valerian-based phytoterapeutic medicine may interact with barbiturates and benzodiazepines, causing an increase in the therapeutic effects of these drugs and potentiating CNS depression.

The option to use valerian, as an alternative to benzodiazepines, was based on the report of its anxiolytic and sedative properties, already demonstrated in clinical and experimental studies. In addition, also based on data from the literature, this phytotherapeutic agent seems to be practically free of side effects, having good acceptance by patients under medical care (Hadley \& Petry, 2003; Pinheiro et al., 2014; Gharib et al., 2015).

As few studies have evaluated the use of valerian in dentistry, well conducted controlled trials are needed to provide a greater amount of evidence on the efficacy of this product concerning conscious sedation (Pinheiro et al., 2014; Farah et al., 2019).

\subsection{Passiflora (Passiflora incarnata)}

In 1569, the Spanish explorer Monardus discovered Passiflora incarnata (Passifloraceae) (Dhawan, Kumar \& Sharma, 2001), also known as passion fruit or passionflower (Fajemiroye et al., 2016). It has sedative and anxiolytic properties (Dhawan, Kumar \& Sharma, 2001; Carlini, 2003; Miroddi et al., 2013; da Cunha et al., 2021). It has been used to treat anxiety, insomnia, drug dependence, mild infections, and pain (Schunck et al., 2017). Additionaly, it can be used to control anxiety caused by dental procedures (Kaviani et al., 2013; da Cunha et al., 2021).

As benzodiazepines cause some undesirable effects during their therapeutic administration (Akhondzadeh et al., 2001), conducted a study comparing a Passiflora incarnata extract (45 mg/day) with oxazepam ( $30 \mathrm{mg} / \mathrm{day})$ in the treatment of generalized anxiety. Results demonstrated that the effect of the passiflora extract had a slower onset, but no decrease in cognitive functions and work performance during use was observed, unlike oxazepam.

Grundmann et al. (2008) carried out a research with the objective of evaluating the anxiolytic properties of a commercial extract phytochemically characterized from Passiflora incarnata in the elevated plus maze test in mice. After oral administration, the extract exerted an anxiolytic effect, which was comparable to that of diazepam $(1.5 \mathrm{mg} / \mathrm{Kg})$ at a dose of 375 $\mathrm{mg} / \mathrm{Kg}$ and exhibited a U-shaped dose-response curve. In addition, they performed antagonistic studies using the antagonist flumazenil for the GABA/benzodiazepine receptors and the antagonist WAY-100635 for the 5-HT1A receptor. The active dose 
was effectively antagonized by flumazenil, but not by WAY-100635. This study was the first in vivo demonstration of the GABA-mediated anxiolytic activity of an extract of Passiflora incarnata.

Movafegh et al. (2008) conducted a randomized, double blind, placebo-controlled clinical trial with 60 patients randomly assigned to receive either Passiflora incarnata $(500 \mathrm{mg}$ ) or placebo as a premedication 90 minutes before the surgery. Anxiety, sedation, and psychomotor function were evaluated. They concluded that the oral administration of Passiflora incarnata as a pre-anesthetic medication reduces anxiety without inducing sedation.

Aslanargun et al. (2012) investigated the effect of pre-operative oral administration of Passiflora incarnata Linneaus on anxiety, psychomotor functions, sedation, and hemodynamics in patients undergoing spinal anesthesia. They concluded that the pre-operative oral administration of Passiflora incarnata Linneaus suppresses the increase of anxiety before spinal anesthesia, being a safe and effective anxiolytic remedy, since it did not alter the result of the psychomotor function test, level of sedation, and hemodynamics.

A study aimed to determine the effectiveness of passionflower in reducing anxiety during dental procedure. Sixty-three patients with moderate, high, and severe anxiety (according to ASA), who required periodontal treatment, participated in the study. In one group, patients received 20 drops of the passionflower extract the night before and 20 drops the morning after the treatment (at least 90 minutes before treatment). In another group, placebo was administered in the same way as the previous group. Finally, a third group received no drugs. It was observed that administration of passionflower, as a pre-medication, is significantly effective in reducing anxiety (Kaviani et al., 2013).

Recently, (Dantas et al., 2017) verified that, when administering Passiflora incarnata (260 mg) or midazolam $(15 \mathrm{mg})$ orally 30 minutes prior to the extraction of impacted mandibular third molars, Passiflora incarnata showed an anxiolytic effect similar to midazolam and was safe and effective for conscious sedation in adult patients who underwent oral surgery. It may be an important pharmacological alternative for the management of anxiety during dental treatment.

Da Cunha (2021) carried out a randomized, triple-blind clinical study with 200 patients who underwent impacted lower third molar extraction, but were asymptomatic. The objective of the research was to compare the anxiolytic effect of $15 \mathrm{mg}$ of Midazolan, with $500 \mathrm{mg}$ of P. incarnata, $500 \mathrm{mg}$ of E. mulungu, in addition to the comparison with the placebo effect, with patients being randomized into four groups where each group received a different medication 60 minutes before the surgical procedure. The participants' anxiety level was assessed using questionnaires and measurements of physical parameters. This work allowed us to conclude that Passiflora incarnata had an effect similar to midazolam, however, placebo and mulungu were not able to control the anxiety of these patients.

No current evidence has revealed any safety problem with the herbal medicine and rarely occur adverse reactions such as nausea, vomiting, headache, tachycardia (Sarris et al., 2011) and anterograde amnesia (Dantas et al., 2017).

Therefore, the genus Passiflora offers immense potential for the creation of new drugs and beneficial products to health. Research in this area will certainly contribute to quality of life improvements for the world population (Trompetter et al., 2013).

\subsection{Kava (Piper methysticum)}

Kava (also known as kava-kava) has been widely used during the last decades. Kava kava gained popularity in western countries due to its anxiolytic properties (Baek et al., 2014). Kavapirones or kavalactones are the 
constituents of the kava-kava phytotherapeutic medicine. This phytotherapeutic, in addition to anxiety control, is used to modulate mood, functions as a skeletal muscle relaxant, and slightly depresses CNS activity (Fajemiroye et al., 2016).

The pharmacological properties of kava include voltage-dependent sodium-channel blockage, increased GABA binding, decreased release of excitatory neurotransmitters due to the blockage of calcium ion channels, neuronal depression and noradrenaline uptake (norepinephrine). Additionally, are also properties of kava the reversible inhibition of monoamine oxidase and the suppression of the eicosanoid thromboxane synthesis activity that antagonizes GABA receptor function (Jamieson \& Duffield, 1990; Singh \& Singh, 2002; Tzeng et al., 2015).

Clinical studies have evaluated the efficacy of a kava extract versus placebo in patients with anxiety symptoms. The results showed a significant decrease of those symptoms (Witte et al., 2005; Sarris et al., 2013). In addition, this phytotherapeutic agent shows satisfactory results regardless of symptoms and type of disorder, including nonspecific anxiety, tension, agitation, phobias, GAD, and insomnia (Baek et al., 2014).

The results of a meta-analysis published by Pittler \& Ernst (2003), which included a total of seven studies with patients with anxiety disorders, indicated a significant reduction of anxiety assessed by the Hamilton Anxiety Scale. However, the randomized, double-blind, placebo-controlled clinical study carried out by Sarris et al. (2020) sought to investigate whether 171 participants diagnosed with generalized anxiety disorder could be effectively treated with kava-kava in two doses of $120 \mathrm{mg}$ administered twice daily. The results showed that this specific extract was not effective as a treatment for generalized anxiety disorder. However, in cases of "situational" anxiety, such as what happens in dental offices, this medication can be configured as a viable anxiolytic, as it has a short-term sedation potential.

The systematic literature review carried out by Araújo et al. (2021) pointed out that the most used and effective medications for controlling anxiety in dental patients were alprazolam (0.5 and $0.75 \mathrm{mg})$, midazolam $15 \mathrm{mg}$, Passiflora incarnata $260 \mathrm{mg}$ and Valeriana officinalis $100 \mathrm{mg}$. most mentioned drugs in terms of adverse effects. Which makes many patients prefer not to use these medications, making the professional look for new alternatives in these cases. Therefore, a detailed analysis in relation to the patient and his anxiety level must be performed beforehand so that the most appropriate medication can be used.

\section{Final Considerations}

Herbal agents are considered to be relatively safe, effective and inexpensive drugs that cause smaller side effects when compared to benzodiazepines. The main advantage is the lesser concentration of active principles achieving better effects, being a replacement alternative to the excessive use of the anxiolytics. However, the use of these medicinal plants need more investigation regarding their real efficacy, correct dosage, and side effects in conscious sedation in Dentistry. Randomized clinical studies to evaluate the effects, possibilities of use and comparison of the effects between herbal medicines and other methods of controlling dental anxiety should be carried out to support and encourage the use of this method of sedation.

\section{References}

Ahmadi, M., Khalili, H., Abbasian, L., \& Ghaeli, P. (2017). Effect of Valerian in Preventing Neuropsychiatric Adverse Effects of Efavirenz in HIV-Positive Patients: A Pilot Randomized, Placebo-Controlled Clinical Trial. The Annals of pharmacotherapy, 51(6), 457-464.

Akhondzadeh, S., Naghavi, H. R., Vazirian, M., Shayeganpour, A., Rashidi, H., \& Khani, M. (2001). Passionflower in the treatment of generalized anxiety: a pilot double-blind randomized controlled trial with oxazepam. Journal of clinical pharmacy and therapeutics, $26(5), 363-367$.

Andreatini, R., \& Leite, J. R. (1994). Effect of valepotriates on the behavior of rats in the elevated plus-maze during diazepam withdrawal. European journal of pharmacology, 260(2-3), 233-235. 
Araújo, J. O., Motta, R., Bergamaschi, C. C., Guimarães, C. C., Ramacciato, J. C., de Andrade, N. K., Fiqueiró, M. F., \& Lopes, L. C. (2018). Effectiveness and safety of oral sedation in adult patients undergoing dental procedures: protocol for a systematic review. BMJ open, 8(1), $176-181$.

Aslanargun, P., Cuvas, O., Dikmen, B., Aslan, E., \& Yuksel, M. U. (2012). Passiflora incarnata Linneaus as an anxiolytic before spinal anesthesia. Journal of anesthesia, 26(1), 39-44.

Baek, J. H., Nierenberg, A. A., \& Kinrys, G. (2014). Clinical applications of herbal medicines for anxiety and insomnia, targeting patients with bipolar disorder. The Australian and New Zealand journal of psychiatry, 48(8), 705-715.

Baldwin, D. S., \& Polkinghorn, C. (2005). Evidence-based pharmacotherapy of Generalized Anxiety Disorder. The international journal of neuropsychopharmacology, 8(2), 293-302.

Becker, A., Felgentreff, F., Schröder, H., Meier, B., \& Brattström, A. (2014). The anxiolytic effects of a Valerian extract is based on valerenic acid. BMC complementary and alternative medicine, 14, 267.

Behboodi Moghadam, Z., Rezaei, E., Shirood Gholami, R., Kheirkhah, M., \& Haghani, H. (2016). The effect of Valerian root extract on the severity of pre menstrual syndrome symptoms. Journal of traditional and complementary medicine, 6(3), 309-315.

Bos, R., Hendriks, H., Scheffer, J. J., \& Woerdenbag, H. J. (1998). Cytotoxic potential of valerian constituents and valerian tinctures. Phytomedicine : international journal of phytotherapy and phytopharmacology, 5(3), 219-225.

Carlini E. A. (2003). Plants and the central nervous system. Pharmacology, biochemistry, and behavior, 75(3), 501-512.

da Cunha, R. S., Amorim, K. S., Gercina, A. C., de Oliveira, A., Dos Santos Menezes, L., Groppo, F. C., \& Souza, L. (2021). Herbal medicines as anxiolytics prior to third molar surgical extraction. A randomized controlled clinical trial. Clinical oral investigations, 25(3), 1579-1586.

Dantas, L. P., de Oliveira-Ribeiro, A., de Almeida-Souza, L. M., \& Groppo, F. C. (2017). Effects of passiflora incarnata and midazolam for control of anxiety in patients undergoing dental extraction. Medicina oral, patologia oral y cirugia bucal, 22(1), 95-101.

Dhawan, K., Kumar, S., \& Sharma, A. (2001). Anti-anxiety studies on extracts of Passiflora incarnata Linneaus. Journal of ethnopharmacology, 78(2-3), 165170 .

Deogade, S. C., \& Suresan, V. (2016). Psychometric assessment of anxiety with the Modified Dental Anxiety Scale among central Indian adults seeking oral health care to a dental school. Industrial psychiatry journal, 25(2), 202-209.

Facco, E., \& Zanette, G. (2017). The Odyssey of Dental Anxiety: From Prehistory to the Present. A Narrative Review. Frontiers in psychology, 8 , 1155.

Fajemiroye, J. O., da Silva, D. M., de Oliveira, D. R., \& Costa, E. A. (2016). Treatment of anxiety and depression: medicinal plants in retrospect. Fundamental \& clinical pharmacology, 30(3), 198-215.

Farah, G. J., Ferreira, G. Z., Danieletto-Zanna, C. F., Luppi, C. R., \& Jacomacci, W. P. (2019). Assessment of Valeriana officinalis 1. (Valerian) for Conscious Sedation of Patients During the Extraction of Impacted Mandibular Third Molars: A Randomized, Split-Mouth, Double-Blind, Crossover Study. Journal of oral and maxillofacial surgery : official journal of the American Association of Oral and Maxillofacial Surgeons, 77(9), 1796-17968.

Fernández-San-Martín, M. I., Masa-Font, R., Palacios-Soler, L., Sancho-Gómez, P., Calbó-Caldentey, C., \& Flores-Mateo, G. (2010). Effectiveness of Valerian on insomnia: a meta-analysis of randomized placebo-controlled trials. Sleep medicine, 11(6), 505-511.

Gharib, M., Samani, L. N., Panah, Z. E., Naseri, M., Bahrani, N., \& Kiani, K. (2015). The effect of valeric on anxiety severity in women undergoing hysterosalpingography. Global journal of health science, 7(3), 358-363.

Gordon, D., Heimberg, R. G., Tellez, M., \& Ismail, A. I. (2013). A critical review of approaches to the treatment of dental anxiety in adults. Journal of anxiety disorders, 27(4), 365-378.

Groppo, F. C., Bergamaschi, C., Cogo, K., Franz-Montan, M., Motta, R. H., \& de Andrade, E. D. (2008). Use of phytotherapy in dentistry. Phytotherapy research : PTR, 22(8), 993-998.

Grundmann, O., Wang, J., McGregor, G. P., \& Butterweck, V. (2008). Anxiolytic activity of a phytochemically characterized Passiflora incarnata extract is mediated via the GABAergic system. Planta medica, 74(15), 1769-1773.

Hadley, S., \& Petry, J. J. (2003). Valerian. American family physician, 67(8), 1755-1758.

Hendriks, H., Bos, R., Woerdenbag, H. J., \& Koster, A. S. (1985). Central nervous depressant activity of valerenic Acid in the mouse. Planta medica, 51(1), 28-31.

Jamieson, D. D., \& Duffield, P. H. (1990). The antinociceptive actions of kava components in mice. Clinical and experimental pharmacology \& physiology, 17(7), 495-507.

Jung, H. Y., Yoo, D. Y., Nam, S. M., Kim, J. W., Choi, J. H., Yoo, M., Lee, S., Yoon, Y. S., \& Hwang, I. K. (2015). Valerenic Acid Protects Against Physical and Psychological Stress by Reducing the Turnover of Serotonin and Norepinephrine in Mouse Hippocampus-Amygdala Region. Journal of medicinal food, 18(12), 1333-1339.

Kaviani, N., Tavakoli, M., Tabanmehr, M., \& Havaei, R. (2013). The efficacy of passiflora incarnata linnaeus in reducing dental anxiety in patients undergoing periodontal treatment. Journal of dentistry (Shiraz, Iran), 14(2), 68-72.

Kinrys, G., Coleman, E., \& Rothstein, E. (2009). Natural remedies for anxiety disorders: potential use and clinical applications. Depression and anxiety, 26(3), 259-265. 
Leuschner, J., Müller, J., \& Rudmann, M. (1993). Characterisation of the central nervous depressant activity of a commercially available valerian root extract. Arzneimittel-Forschung, 43(6), 638-641.

Liu, L., Liu, C., Wang, Y., Wang, P., Li, Y., \& Li, B. (2015). Herbal Medicine for Anxiety, Depression and Insomnia. Current neuropharmacology, 13(4), 481-493.

Loeffler P. M. (1992). Oral benzodiazepines and conscious sedation: a review. Journal of oral and maxillofacial surgery : official journal of the American Association of Oral and Maxillofacial Surgeons, 50(9), 989-997.

Movafegh, A., Alizadeh, R., Hajimohamadi, F., Esfehani, F., \& Nejatfar, M. (2008). Preoperative oral Passiflora incarnata reduces anxiety in ambulatory surgery patients: a double-blind, placebo-controlled study. Anesthesia and analgesia, 106(6), 1728-1732.

Manayi, A., Nabavi, S. M., Daglia, M., \& Jafari, S. (2016). Natural terpenoids as a promising source for modulation of GABAergic system and treatment of neurological diseases. Pharmacological reports : PR, 68(4), 671-679.

Mancuso, C. E., Tanzi, M. G., \& Gabay, M. (2004). Paradoxical reactions to benzodiazepines: literature review and treatment options. Pharmacotherapy, 24(9), 1177-1185.

Miroddi, M., Calapai, G., Navarra, M., Minciullo, P. L., \& Gangemi, S. (2013). Passiflora incarnata L.: ethnopharmacology, clinical application, safety and evaluation of clinical trials. Journal of ethnopharmacology, 150(3), 791-804.

Murphy, K., Kubin, Z. J., Shepherd, J. N., \& Ettinger, R. H. (2010). Valeriana officinalis root extracts have potent anxiolytic effects in laboratory rats. Phytomedicine: international journal of phytotherapy and phytopharmacology, 17(8-9), 674-678.

Ouzzani, M., Hammady, H., Fedorowicz, Z., \& Elmagarmid, A. (2016). Rayyan-a web and mobile app for systematic reviews. Syst Rev, 5(1), 210. https://doi.org/10.1186/s13643-016-0384-4.

Pakseresht, S., Boostani, H., \& Sayyah, M. (2011). Extract of valerian root (Valeriana officinalis L.) vs. placebo in treatment of obsessive-compulsive disorder: a randomized double-blind study. Journal of complementary \& integrative medicine, 8, /j/jcim.2011.8.issue-1/1553-3840.1465/1553-3840.1465.xml.

Pereira, R. P., Fachinetto, R., de Souza Prestes, A., Wagner, C., Sudati, J. H., Boligon, A. A., Athayde, M. L., Morsch, V. M., \& Rocha, J. B. (2011). Valeriana officinalis ameliorates vacuous chewing movements induced by reserpine in rats. Journal of neural transmission (Vienna, Austria : 1996), 118(11), $1547-1557$.

Pinheiro, M. L., Alcântara, C. E., de Moraes, M., \& de Andrade, E. D. (2014). Valeriana officinalis L. for conscious sedation of patients submitted to impacted lower third molar surgery: A randomized, double-blind, placebo-controlled split-mouth study. Journal of pharmacy \& bioallied sciences, 6(2), 109-114.

Pittler, M. H., \& Ernst, E. (2003). Kava extract for treating anxiety. The Cochrane database of systematic reviews, (1), CD003383.

Ricigliano, V., Kumar, S., Kinison, S., Brooks, C., Nybo, S. E., Chappell, J., \& Howarth, D. G. (2016). Regulation of sesquiterpenoid metabolism in recombinant and elicited Valeriana officinalis hairy roots. Phytochemistry, 125, 43-53.

Sarris, J., Byrne, G. J., Bousman, C. A., Cribb, L., Savage, K. M., Holmes, O., Murphy, J., Macdonald, P., Short, A., Nazareth, S., Jennings, E., Thomas, S. R., Ogden, E., Chamoli, S., Scholey, A., \& Stough, C. (2020). Kava for generalised anxiety disorder: A 16-week double-blind, randomised, placebo-controlled study. The Australian and New Zealand journal of psychiatry, 54(3), 288-297.

Sarris, J., McIntyre, E., \& Camfield, D. A. (2013). Plant-based medicines for anxiety disorders, part 2: a review of clinical studies with supporting preclinical evidence. CNS drugs, 27(4), 301-319.

Sarris, J., Panossian, A., Schweitzer, I., Stough, C., \& Scholey, A. (2011). Herbal medicine for depression, anxiety and insomnia: a review of psychopharmacology and clinical evidence. European neuropsychopharmacology: the journal of the European College of Neuropsychopharmacology, 21(12), $841-860$.

Schunck, R., Macedo, I. C., Laste, G., de Souza, A., Valle, M., Salomón, J., Nunes, E. A., Campos, A., Gnoatto, S., Bergold, A. M., Konrath, E. L., Dallegrave, E., Arbo, M. D., Torres, I., \& Leal, M. B. (2017). Standardized Passiflora incarnata L. Extract Reverts the Analgesia Induced by Alcohol Withdrawal in Rats. Phytotherapy research : PTR, 31(8), 1199-1208.

Singh, Y. N., \& Singh, N. N. (2002). Therapeutic potential of kava in the treatment of anxiety disorders. CNS drugs, 16(11), 731-743.

Thomas, K., Canedo, J., Perry, P. J., Doroudgar, S., Lopes, I., Chuang, H. M., \& Bohnert, K. (2016). Effects of valerian on subjective sedation, field sobriety testing and driving simulator performance. Accident, analysis and prevention, 92, 240-244.

Trompetter, I., Krick, B., \& Weiss, G. (2013). Herbal triplet in treatment of nervous agitation in children. Wiener medizinische Wochenschrift (1946), 163(34), 52-57.

Tzeng, Y. M., \& Lee, M. J. (2015). Neuroprotective properties of kavalactones. Neural regeneration research, 10(6), 875-877.

Ugalde, M., Reza, V., González-Trujano, M. E., Avula, B., Khan, I. A., \& Navarrete, A. (2005). Isobolographic analysis of the sedative interaction between six central nervous system depressant drugs and Valeriana edulis hydroalcoholic extract in mice. The Journal of pharmacy and pharmacology, 57(5), 631639.

Vanhee, T., Mourali, S., Bottenberg, P., Jacquet, W., \& Vanden Abbeele, A. (2020). Stimuli involved in dental anxiety: What are patients afraid of?: A descriptive study. International journal of paediatric dentistry, 30(3), 276-285. 
Research, Society and Development, v. 10, n. 16, e199101623528, 2021

(CC BY 4.0) | ISSN 2525-3409 | DOI: http://dx.doi.org/10.33448/rsd-v10i16.23528

Witte, S., Loew, D., \& Gaus, W. (2005). Meta-analysis of the efficacy of the acetonic kava-kava extract WS1490 in patients with non-psychotic anxiety disorders. Phytotherapy research: PTR, 19(3), 183-188.

Yao, M., Ritchie, H. E., \& Brown-Woodman, P. D. (2007). A developmental toxicity-screening test of valerian. Journal of ethnopharmacology, 113(2), 204209. 